\title{
Ressonância magnética no diagnóstico precoce de pré-fratura em um equino da raça Puro Sangue Inglês
}

Matheus Dias Cunha", Julio Cesar Paganela, Bruna Patricia Siqueira Raimundo

Horse Center, Petrópolis, RJ, Brasil

*Autor correspondente

e-mail: matheusdmcunha@hotmail.com

\section{Resumo}

A ressonância magnética atualmente se mostra como o método mais eficaz na identificação de diversas lesões atribuídas ao sistema locomotor dos equinos, sendo considerada diagnóstico gold standard para alterações de casco e boleto. As fraturas por estresse são lesões que podem comprometer toda a vida esportiva de cavalos atletas. Lesões na porção distal do osso metacarpiano/metatarsiano, nos côndilos, são comumente vistas em animais jovens que iniciam sua carreira esportiva e os treinamentos precocemente. A ressonância magnética é o único método diagnóstico que possibilita a identificação precoce das fraturas condilares, onde é possível visualizar áreas de pré-fratura e, assim, prevenir lesões mais severas e/ou a fratura completa. 0 objetivo deste trabalho é relatar a identificação de uma área de pré-fratura, através da ressonância magnética, em um animal que se apresentava claudicante, sem qualquer alteração no exame radiográfico. Foi atendido na clínica veterinária Horse Center um animal da raça Puro Sangue Inglês, com aproximadamente 3 anos de idade, claudicação grau 2, responsivo ao bloqueio dos seis pontos baixos, sem efusão ou dor à flexão do boleto do membro posterior esquerdo. Radiografias das regiões do casco, quartela e boleto do membro claudicante foram realizadas, nas projeções lateromedial, dorsopalmar e oblíquas, porém nenhuma alteração significativa foi constatada. Na avaliação ultrassonográfica do boleto também não havia nenhuma alteração. Sendo assim, o animal foi encaminhado para a ressonância magnética, onde a região do boleto foi analisada. 0 animal apresentava áreas de esclerose no côndilo lateral do metatarso em todas as sequências utilizadas, como T1 GRE, T2* e T2FSE. A área de esclerose é identificada por áreas de hipointensidade na região condilar; associada a esta, observou-se a presença de líquido inflamatório no osso subcondral, sugestivo de um edema ósseo, caracterizado por uma área de hipersintensidade na sequência STIR. O quadro caracteriza um processo subagudo de doença osteocondral palmar, com área de edema ósseo, caracterizando um local de pré-fratura. 0 repouso e paralização dos treinamentos foram indicados 
por aproximadamente 90 dias como tentativa de reduzir o impacto na região e, dessa forma, impedir a progressão do processo. Após o período de repouso absoluto, o animal passou por nova avaliação através do exame de ressonância magnética, onde verificou-se redução da área de esclerose e a não presença de área de edema ósseo, característico da pré-fratura diagnosticada; com isso, houve cicatrização da lesão e o animal foi liberado para retornar às atividades. Com esse estudo foi possível notar que a ressonância magnética se mostra como método mais preciso e eficiente na identificação de áreas de pré-fraturas, podendo desta forma ser utilizada de forma preventiva, facilitando o tratamento precoce dessas lesões, e de forma conservadora, diminuindo os riscos e o comprometimento da carreira atlética dos animais acometidos.

Palavras-chave: Ressoância magnética. Pré-fraturas. Doença osteocondral palmar. 